\title{
Twentieth-Century Enterprise Forms: Japan in Comparative Perspective
}

\author{
LESLIE HANNAH \\ MAKOTO KASUYA
}

La Porta et al. see common law as most favorable to corporate development and economic growth, but Japanese legislators explicitly based their system on German civil law. However, Japan's commercial code of 1899 omitted the $\mathrm{GmbH}$ (private company) form, which Guinnane et al. see as the jewel in the crown of Germany's organizational menu. Neither apparent "mistake" retarded Japan's adoption of the corporate form, because its commercial code offered flexible governance and liability options, implemented liberally. It was this liberal flexibility, not choice of legal family or hybrid corporate forms emphasized by previous writers, that drove corporatization forward in Japan and more widely. Surprisingly (given that Germany's superficially fuller organizational menu predated Japan's by many decades and the country was wealthier), by the 1930 s Japan already had not only more corporations than Germany, but also more commandite partnerships (with some corporate characteristics). After the introduction of the yugen kaisha (private company) in 1940, corporate forms became nearly as widely used in Japan as in the United States, United Kingdom, or Switzerland.

(C) The Author 2015. Published by Cambridge University Press on behalf of the Business History Conference.

doi:10.1017/eso.2015.51

Published online September 15, 2015

Leslie Hannah is Visiting Professor of Economic History at the London School of Economics. Contact information: Department of Economic History, LSE, Houghton St, London WC2A 2AE, UK. Email: lesliehannah@hotmail.com.

Makoto Kasuya is a professor of business history at the University of Tokyo. Contact information: Faculty of Economics, University of Tokyo,7-3-1 Hongo, Bunkyo-ku, Tokyo 113-0033 Japan. Email: kasuya@e.u-tokyo.ac.jp.

The authors thank participants in Business History Society of Japan and Bank of Japan seminars, Brian Cheffins, Tetsuji Okazaki, Takeshi Yuzawa, three referees, and the editor for their comments. 
"[T]he dominant scholarly effort was to try to fit the world into simple models and to criticize institutional arrangements that did not fit."

—Elinor Ostrom, Nobel Lecture, American Economic Review

2010, p. 642

Corporate laws-and the differential effects of their menus of organizational forms on business efficiency-have recently attracted attention. La Porta and researchers connected with the World Bank proposed the "law and finance" hypothesis: that common-law systems (concentrated in the "Anglosphere")1 ${ }^{1}$ promoted stock exchange development, optimal business contracting, new business formation and economic efficiency. ${ }^{2}$ By contrast, the Franco-German civil-law systems of continental Europe-and offshoots throughout Latin America and in most of Asia-were less conducive to corporate development. Criticizing this view, Guinnane et al. argued in this journal that civil-law systems had advantages over U.S. common law, ${ }^{3}$ particularly for small and medium enterprises (SMEs). Downgrading the classic corporation to what they consider its distinctly limited place, they praise innovative European forms, notably the $\mathrm{GmbH}$ (introduced in 1892 in Germany and 1906 in Austria) and the SARL (introduced in 1925 in France) as offering contractual choices more suited to SMEs than conservative and inflexible U.S. corporate law.

If either (or both) ${ }^{4}$ of these hypotheses applies to Japan, its economy before 1940 was legally backward and organizationally disadvantaged. Meiji reformers were keen to copy Western models but (after an unhappy flirtation with American-style national banking corporations in 1872-1879) decided that the clarity of civil law commercial codes was preferable to Anglo-American judicial discretion, and Meiji autocrats were increasingly attracted to the "top-down" approach that they detected in Germany. After some discussion of French and English commercial laws-and under pressure to adopt Western laws to facilitate reassertion of national control in the treaty ports-the definitive Japanese commercial code of 1899 clearly owed most to Germany's Handelsgesetzbuch. The characterization of Japanese law as an offshoot of German civil law (at least before

1. I.e., the United States, UK, India, Hong Kong, Australia, Israel, and other heirs of British Empire institutions, with exceptions such as Louisiana, Quebec, Scotland, Mauritius, or Malta, which retained civil law systems.

2. La Porta et al., "Law and Finance" and "Economic Consequences"; Djankov et al., "Regulation."

3. Though not the UK, whose "private company" law of 1907 was considered similar to civil law hybrid forms; see Guinnane et al., "Putting" and "Pouvoir."

4. Arguably, the first applies more to large quoted companies and the second to unquoted SMEs. 
externally imposed post-1945 legal Americanization) is widely accepted; however, Guinnane et al.'s alleged advantage of the German system, the $\mathrm{GmbH}$, was rejected in the interim Japanese commercial code of 1893 and still omitted from the definitive commercial code of 1899. ${ }^{5}$ It was thus not available to Japanese entrepreneurs for nearly half a century after its introduction in Germany: The yugen kaisha was introduced as late as 1940 and never became as widely used in Japan as the GmbH in Germany. ${ }^{6}$

Before concluding that Japanese legislators were incompetent, it is worth noting that lawyers have been skeptical about the hypotheses, ${ }^{7}$ which historians and economists have also questioned: La Porta et al.'s extensively, ${ }^{8}$ Guinnane et al.'s more tentatively. ${ }^{9}$ Moreover, the Japanese code of 1899 was much more than a foolishly truncated copy of German law. We argue here that it offered a flexible organizational menu, molded by entrepreneurs to the needs of a developing nation's diverse business organizations. By contrast, German corporations-under formally similar laws-were handicapped by illiberal statutory and administrative provisions, later amplified by authoritarian absurdities. Japan and its colonies allowed more legal elasticity, so their corporate laws-despite their German roots-well and flexibly served the needs of capitalists, including the SMEs on which Guinnane et al. focus, well before the 1940 innovation of the yugen kaisha. Germany's Sonderweg in corporate matters is not representative even of countries that shared its legal tradition: as we shall see, many had more liberal regimes than Germany and hence more companies per capita, even before they introduced the private company form.

Various metrics have been proposed to assess the impact of legal menus on levels of corporatization. ${ }^{10}$ Guinnane et al. count changing

5. The government's German legal adviser, Roesler, suggested what was effectively a $\mathrm{GmbH}$ (a sakin kaisha or limited partnership in which all partners were limited) in 1884, before German GmbHs legislation, and it was included in the tentative 1890 commercial code, but omitted from the 1893 implementation (individually authorized goshi kaisha then required at least one unlimited partner, conforming to the internationally standard commandite form). There was little interest in the $\mathrm{GmbH}$ proper; it appears to have first been discussed in a Japanese academic article as late as 1907 (Yamazaki, "Doitsu”).

6. In 1995, there were 1,219,214 yugen kaisha and 1,213,034 KKs, a pattern very similar to Switzerland's, whose corporate laws Japan's more closely resembled. By contrast, in Germany, GmbHs (sometimes in hybrids with other forms which were illegal in Japan) were overwhelmingly numerically dominant.

7. Cheffins, "Did Law"; Coffee, "Rise."

8. Musacchio and Turner, "Does the Law."

9. Hilt, "Corporate Governance,” p. 233; Hannah, "Global Corporate Census," p. 553 , n. 33 .

10. The World Bank's Doing Business indicators use more eclectic metrics, for which long-run historical data are largely lacking. 
stocks (and flows) of registered private companies relative to alternative business forms; we extend their approach in the next section by comparing the numerical stocks of all corporations at decade intervals in five countries over the entire twentieth century (normalized in per capita terms), finding that Germany was the laggard among the advanced countries considered, and was soon overtaken by Japan. An alternative measure is paid-up capital of all companies relative to GDP (giving greater weight to large firms), but this is correlated with a variant of our numbers measure in $1910^{11}$ and after 1914 differential inflation and deflation make it difficult to compare this measure internationally. We treat private companies as corporations proper, but they might be considered hybrids, so the next section compares them with other quasi-corporate forms. Equity market capitalizations relative to GDP (the variant suggested by La Porta et al. for assessing the impact of investor protection) are then considered. The following section assesses whether Japan's corporate development typifies a distinctive Asia-Pacific model of pyramided holding companies and family enterprise groups. Although the impact of national laws on the level of corporatization is the main focus of this article, our conclusion places these findings in the context of related research on the impact of corporatization on growth, on which La Porta et al. acknowledge that their positive findings are least robust and Guinnane et al. are agnostic.

\section{A Statistical Framework}

Central to our assessment is the notion of revealed preference: If a legal template for organizing business is widely adopted, we presume that it offers something valued by those taking it up (at least) and (possibly) by society at large. However, creditors might reasonably view limited liability less favorably than incorporators, and Guinnane et al.'s tentative agnosticism about whether higher take-up of a particular form is efficient or socially beneficial is well taken. It is also conceivable that a system of total liberty would be so abused as to undermine faith in the capitalist system, leading to fewer corporations, but in fact this did not happen, even in the most liberal regime. ${ }^{12}$ Flexibility may

11. Spearman's rank correlation coefficient for the minority of 34 countries for which both measures are available is 0.78 (Hannah, "Global Census," p. 557).

12. Norway, where there was almost total freedom of private contracting for enterprise forms until 1910, had more corporations per capita than elsewhere in Europe, although its new statutory template then set basic norms: Hannah, "Global Census," pp. 550, 558. However, compare Foreman-Peck and Hannah ("Diffusion," pp. 20-21) for a Norwegian opinion, possibly for good reason, favoring a new statutory template. 
nonetheless bias the type of company being formed. For example, allowing directors to entrench their position to the detriment of outside shareholders might encourage incorporation by family oligarchs, while discouraging public offerings (although legislation reserved for quoted companies or stock exchange listing rules might separately promote the latter). Guinnane et al., interestingly, suggest that flexible internal governance rules drove high take-up of the private company, allowing businesses to limit the threat of untimely dissolution inherent in partnerships without taking on the full risk of minority oppression facilitated by classic corporations. They also point to other possible encouragements offered by legal forms, including cheaper registration costs, the ability to entrench senior management or minority veto rights, and lighter regulatory burdens (which in some countries were more attractive than in Germany). Other possible attractions-also varying internationally-included an administrative process capable of registering a company in hours, not weeks; minimal publicity; paralegal intermediaries selling "off-the-shelf" companies; regionally devolved registration offices; the absence of minimum required capital; tax privileges; not requiring an expensive notary to endorse changes in ownership or charter conditions; minimal annual reregistration requirements; and (in the extreme) not having secret police and a cowed judiciary endorsing their expropriations. Our measure of the take-up of various business forms captures only the net effect of the whole package of liberal flexibility (combined with any other determinants); other means (econometric or archival) must be found to distinguish their relative importance.

Comprehensive annual statistics on the numbers and capitals of extant stocks of all multi-owner business forms are not available for most countries for the twentieth century as a whole. Several series, however, are available annually for Japan from 1883 to the present for all forms in the commercial code and can be linked to form one continuous series (see the online appendix). For the four other countries in Table 1, we have similarly comprehensive statistics only for fully corporate forms (defined here as Japan's kabushiki kaisha (KKs) ${ }^{13}$ plus yugen kaisha, in the UK public plus private companies, in the United States quoted plus close corporations, in Germany AGs plus GmbHs, and in Switzerland SAs plus SARLs). ${ }^{14}$ Partnership forms

13. We follow contemporary statistical practice by including kabushiki goshi kaisha/Kommanditgesellschaften auf Aktien (KGaAs, or limited partnerships with transferable shares) with KKs/AGs. In the twentieth century, there were few in either country.

14. See Table 2. France is not included, because its statistics are better on flows of new registrations than on stocks of extant ones shown in the table; stock figures are available only at irregular intervals. They do, however, indicate that France 
Table 1 Extant stocks of (private and public) corporations per million people, 1899-1999

\begin{tabular}{rrrrrr}
\hline Year & \multicolumn{1}{c}{ US } & \multicolumn{1}{c}{ UK } & Germany & Switzerland & Japan \\
\hline 1899 & 1,875 & 684 & 174 & 615 & 89 \\
1909 & 2,901 & 1,044 & 341 & 961 & 117 \\
1919 & 2,778 & 1,576 & 604 & 1,827 & 302 \\
1929 & 3,895 & 2,412 & 851 & 3,177 & 331 \\
1939 & 3,584 & 3,486 & 415 & 4,547 & 452 \\
1949 & 4,121 & 4,974 & 486 & 4,761 & 2,081 \\
1959 & 6,064 & 6,825 & 725 & 6,248 & 4,861 \\
1969 & 8,182 & 9,666 & 1,265 & 10,216 & 7,868 \\
1979 & 11,358 & 13,978 & 3,706 & 16,807 & 11,634 \\
1989 & 14,605 & 20,181 & 6,513 & 23,198 & 15,527 \\
1999 & 19,778 & 23,866 & 10,846 & 28,947 & 19,384 \\
\hline
\end{tabular}

Source: Online appendix to this article.

are necessarily excluded, because outside Japan, their numbers are rarely reported annually with precision. To assess the level of corporatization in these nations of vastly different-and differentially changing-sizes, we have divided the numbers of corporations by their national populations at all dates.

The most obvious feature of Table 1 is that the common-law countries (the United States and United Kingdom) were ahead of both Germany and Japan at the beginning of the twentieth century and remained so at the end. If the corporate form (as defined in this table) had advantages, these two common-law nations apparently benefited earlier and more abundantly. However, the example of civil-law Switzerland suggests that legal family was no barrier to rapid catch-up. Swiss corporate law, owing something to German stems, was on a federal rather than cantonal basis and (although Swiss lawyers debated developments elsewhere) developed independently. The number of corporations per capita in Switzerland (already ahead of Germany from the earliest available statistical counts) overtook the United Kingdom during World War I and the United States in the 1930s; it remained the leader of this group for the rest of the century. Moreover, Switzerland was not unique among northwest European countries with civil law regimes: Norway, Sweden, Denmark, Finland, the Netherlands, and Luxembourg were all (at various stages of the twentieth century)

resembled Germany in numbers of corporations as defined here (according to Bozio's extrapolations from a 1921 observation ["Capitalisation,” p. 110], the figures for 1900, 1909, 1919, and 1929 were (converted to per million terms) 215, 363, 524, and 986), although France probably made more extensive use of commandites before the introduction of the SARL private company form in 1925. It then moved ahead of Germany (with more than twice the German per capita level of corporatization in the later 1930s) and remained slightly ahead of Germany at the end of the century (authors' calculation from SIRENE database). 
nearer to the high Swiss than to the modest German levels of corporatization. Although common-law nations led corporatization at the beginning of the century, civil-law nations experienced more rapid growth in corporate numbers, so there was some convergence. It was quite rare for (non-communist) societies to experience a reduction in the numbers of corporations per capita over a sustained period, but some countries managed it. Germany appears to hold the record for the longest sustained early decline (which can be more precisely dated from 1923 to around 1948), but even the United States experienced a temporary check during the 1930s depression. Factors other than the (unchanging) legal family evidently determined these variations. Foreman-Peck and Hannah's ("Diffusion") econometric analysis of an international cross section before 1914 suggests that more fundamental determinants of corporatization were living standards (proxied by GDP per capita) and the degree of liberality and openness in economic policy (proxied by openness to international trade). The latter is closely correlated with more corporation-friendly legal systems, in both common and civil law nations.

How does Japan fit into this picture? As Table 1 shows, in the early twentieth century it had relatively few corporations. Japan was still an early-stage industrializer but it had also come late to allowing incorporation without individual state sanction (as had become the norm in western Europe, the United States, and some of the developing world by the 1870s). Nonetheless, in the postwar miracle years, Japan came to have corporate numbers comparable with other leading nations, and at the end of the century it had numbers of corporations per million people almost as high as the United States and well ahead of Germany. Japan had already overtaken Germany's corporations per capita in the 1930s (when it still had much lower living standards), confirming that adopting a civil law system-even one based on the German code but without the $\mathrm{GmbH}$ - did not especially inhibit incorporation.

However, Germany was by then a very soft target. Its declining corporate numbers, beginning a decade before Hitler's 1933 election victory, were further reduced by Nazi policies under his dictatorship. These condemned outside shareholders as leeches on managerial creativity, reduced shareholder protections, restricted dividends and stock issues, expropriated Jewish companies, and provided strong incentives for Aryans to convert their corporations to partnership form. ${ }^{15}$ Other right-wing authoritarian regimes, such as those of Japan

15. Despite this, the obvious alternative form-Kommanditgesellschaft (KG) was not as popular in Germany as goshi kaisha in Japan at the same time. In 1938 (in the boundaries of the Old Reich-i.e., excluding Austria, etc.), there were 22 KGaAs, 5,493 AGs, 25,625 GmbHs, and 233 Gewerkschaften (a total of 31,373 for 
and Italy, shared only some anti-corporate prejudices and did not emulate the more extreme of these policies. Like many combatants, the Japanese government (on a full war footing in 1937-1945) naturally restricted dividends and concentrated existing corporations on armaments production, but its overall numbers of corporations consistently increased, with only slight and temporary setbacks. ${ }^{16}$

\section{Alternative Business Forms}

The statistics for corporations in Table 1 arguably understate Japan's early position. Statisticians and lawyers (even within the same legal family) draw the dividing lines among enterprise forms in different places, not always using identical logic or language in doing so and sometimes blurring lines of division other nations consider clear. As Elinor Ostrom insists in different contexts, many cooperative, multiagent contractual relations may function in a coherent manner, without conforming to a market/hierarchy/state trichotomy. ${ }^{17}$ Table 2 illustrates some of the issues in multi-owner organizations, although forms masquerading as linguistic equivalents in the organizational menus of this table conceal considerable variations (anyone who has ordered spaghetti bolognese in Bologna, Los Angeles, and Tokyo will understand the problem of menus). ${ }^{18}$ Corporations- the first two columns-encompass two types (although their legal separation in many countries came only in the second half of the twentieth century): public companies, which could be (but were not necessarily) quoted; and private companies, not offering stock to the public. Some countries exempted private companies from requirements to publish accounts and restricted their shareholder numbers (for example, Japan and the United Kingdom, but not Germany, imposed maximum numbers of fifty). By this period, stockholders normally (but not invariably) had

all corporations), compared with only 13,142 KGs (Wirtschaft und Statistik, no 24, 1939, pp. 771-773), so in 1938 including KGs would increase the corporate total by $42 \%$, compared with $138 \%$ for the equivalent goshi kaisha adjustment in Japan in that year. Numbers in Germany then perhaps most closely approached Japan's high levels: earlier (but less comprehensive) census data suggest a lower portion were KGs in 1907 or 1924. On German policy, see Burhop et al., "Law" and Hannah, "Weimar's Capitalist Spring."

16. At the wartime peak of 1943 , kaisha numbers were $11 \%$ higher than in 1937 and in 1945's devastated economy, they remained 4\% higher (Historical Statistics of Japan, Table 6).

17. See her Nobel lecture, opening quotation above.

18. We do not show Switzerland separately because French and German terminology was used there and (though its laws substantially differed) no new legal principles are illustrated by the Swiss case. 
Table 2 Capitalist enterprise forms in the first half of the twentieth century

\begin{tabular}{|c|c|c|c|c|c|c|}
\hline UK & Public company & Private company & Limited partnership & Ordinary partnership & Special associations* & Sole proprietor \\
\hline US & Corporation & Corporation & Limited Partnership & General partnership & $*$ & Sole proprietor \\
\hline Japan & kabushiki Kaisha & yugen kaishat & goshi kaisha & gomei kaisha & Special kumiai & kojin jigyō sha \\
\hline Germany & AG & $\mathrm{GmbH}$ & KG (Kommandit) & $\mathrm{OHG}$ & $*$ & Alleininhaber \\
\hline France & SA & SARL & SC (commandite) & SNC & $*$ & Propriétaire unique \\
\hline
\end{tabular}

* In addition to kaisha, there were many kumiai (cooperatives or associations) in Japan besides those set up under special legislation from 1900 (the "special" kumiai in column 5). Many similar entities existed in Western countries_-sometimes set up as cooperatives, sometimes as corporations, but also with a wide variety of names, liability regimes, profit distribution rules. and legal status (savings banks, credit unions, mutuals, Vereine, Raffeisen, etc.).

† From 1940. The godo kaisha, introduced in 2006 to succeed the yugen kaisha, is irrelevant for this historical discussion. 
limited liability, whereas partners in ordinary partnerships (column 4) did not. Limited partnerships (column 3) occasionally had fully limited liability, but usually (as in Japan) followed the old European model of the commandite: Managing partners retained full liability and only outside investors had limited liability. This table includes only capitalist enterprises; state and municipal businesses (unless they were organized under the general law for capitalist enterprises) are excluded, as are some older legal forms once common in Europe but approaching extinction ${ }^{19}$ and minor variants that contemporaries treated together with the cases shown. ${ }^{20}$ The order of the six forms shown in the table can be thought of as a ranking: It is broadly true that progressing from public companies to sole proprietors entails a movement toward smaller enterprises, usually with fewer owners and greater personal liability, yet giant enterprises have at times existed in all categories and it is possible for a corporation (de jure or de facto) ${ }^{21}$ to be owned by one person, uniting the extremes.

Cooperatives and mutuals are generally excluded because, though they made and distributed profits, control rights were generally not proportional to the capital subscribed or dividends paid (by then the capitalist norm); instead, each member normally had one vote. However, in Japan, some kinds of kumiai-variously translated as cooperatives, associations, or partnerships-were close counterparts to certain collective business firms in the West. ${ }^{22}$ Kumiai was the term used in the civil code to describe partnerships that had neither separate legal personality nor limited liability. ${ }^{23}$ Many were very similar to

19. The bergrechtliche Gewerkschaft in Germany or the similar "cost-book" mining company in the UK were species of cooperative with distinctly capitalist characteristics and in many cases quoted on stock exchanges, so they were closer to the corporate form than most cooperatives. Japan did not have similar forms.

20. For example, the kabushiki goshi kaisha was a limited partnership with shares, a cross between a KK (it issued shares) and a goshi kaisha (managing partners had unlimited liability).

21. Some jurisdictions recognised “corporations sole," but multi-ownership was usually a necessary condition for incorporation, although such rules were often (and with varying degrees of legal risk) evaded by the appointment of dummy shareholders.

22. Because no statistics are available for any country, we do not consider tokumei kumiai (literally, "anonymous associations”), the Japanese equivalent of Germany's stille Gesellschaften or France's associations en participation. These were loans made by "sleeping" investors on the basis of participating in the borrower's profits, usually incurring no liability for this participation in civil law jurisdictions (or in the UK from 1865), but with a (significant but declining) risk of judicial attribution of partnership liability in the United States.

23. It was also used to describe labor unions (rōdō kumiai) and some social, cultural, and professional associations, as well as some commercial cooperatives and partnerships. 
Western (unlimited) business partnerships, and they had similarly wide freedom to contract and modify contracts when circumstances changed, but responsibility for debts was not (as in the West) joint and several, but proportional to participations in the enterprise (or, if creditors had not been apprised of that, equal liability per partner). ${ }^{24}$ Other kumiai (in the fifth column of Table 2) set up under special legislation in Japan from 1900 (partly modeled, like its corporate law, on German precedent) did have separate legal status; some had limited and some unlimited liability. ${ }^{25}$ Some undertook functions (trade associations, cartels, joint purchasing or credit for farmers or homeowners) that in the West might have been constituted under special legislation, but were sometimes organized as corporations or cooperatives. ${ }^{26}$

In Japan's distinctive terminology, "kaisha" describes all the first four columns in Table 2 (under the commercial code) but none of the remainder (under special legislation or the civil code). This was not the case for similar words for generic types in Western languages. The corporate form was usually confined to the first two columns (public and private companies) in the Anglosphere, whereas Gesellschaft, société, aktiebolag, and the like in continental European languages (and "company" in Victorian British English and modern American English) cover the first four columns but additionally include further types. "Firm" (or even "company") in English can sometimes include sole proprietors, as do non-legal terms like kigyō, "enterprise" or "business" in most languages. Kaisha is usually translated as "company" (in its more restricted modern sense) or "corporation," but is that correct? Not to twentieth-century Anglo-American lawyers. Common-law partnerships did not then have separate legal personality

24. This was under the earlier Japanese civil code (not, as with kaisha, the commercial code); see de Becker, Annotated Civil Code, pp. 240-250. They also differed in sometimes being conducted by a default rule of majority voting of partners and in permitting one partner to be expelled by unanimity of the other partners.

25. For sangyo kumiai under the Industrial Association Law of 1900 see note* to Table 3. On this enterprise form, see Fisher, "Cooperative Movement"; Churchill, "Cooperatives.” There were also dogyo kumiai (trade associations mainly for assuring quality under another 1900 law), suisan kumiai (fishery associations under a 1901 law) and shinrin kumiai (forestry associations under a 1907 law). In 1925, further laws created associations to cartelize exports (kogyo kumiai for manufacturers and yushutshu kumiai for merchants), with stronger controls over nonmembers than dogyo kumiai. Limited liability in the 1930s was discouraged as insufficiently prudent, with cooperatives increasingly adopting "guaranteed" capital, increasing (but still limiting) the liabilities of sangyo kumiai and their members (for the shift see, e.g., Fisher, “Cooperative Movement,” p. 483, and the statistics in Financial and Economic Annual of Japan, 1930-1938.)

26. E.g., Raffeisen cooperatives in Germany, corporate savings banks in the United States, and building societies in the UK. 
in the United States and England,27 but in Japan some typespartnerships (ordinary or limited) under the commercial code (both kaisha) and some (but not all) kumiai-did and even in civil law Scotland, France and Germany partnerships had some characteristics of separate legal entity. ${ }^{28}$

Guinnane et al. (2007) describe the GmbH as a "hybrid"; there was initial contemporary uncertainty about how to describe it. Some, noting the GmbH's corporate form and fully limited liability, translated it as private limited company (close corporation); othersnoting that its ownership stakes were named Anleihen (quotas) rather than Aktien (stocks) and that, as with partnership stakes, they were not tradable on stock exchanges-translated it as limited partnership. The first usage predominated, but the latter has recently been revived in American English, where, from the 1970s, newly legally defined "limited liability companies" (private companies), though sharing most legal characteristics of corporations, are technically considered partnerships. The historically pervasive Anglo-American use of that same term as a synonym for corporation is accordingly falling into disuse in the United States. ${ }^{29}$ Confusingly, "limited liability companies" in British English (in this context, more widely spoken worldwide) ${ }^{30}$ are definitely not partnerships, but corporations proper.

Economists might wish to define the boundaries between enterprises differently from lawyers; the legal categories in Table 2-even if not coinciding exactly with their needs-will sometimes provide serviceable approximations. For example, to measure enterprises

27. Although in practice common law courts struggled to maintain this view (Crane, Handbook, 8-16). In the United States, the revised Uniform Partnership Act of 1997 finally conferred separate legal personality on all partnerships, but implementation by states differed. In England and Wales, from 2000, limited liability partnerships (but not general or limited partnerships) had separate legal personality, like companies, although they continued to be taxed as partnerships. The world is thus now nearer the Japanese usage than it was historically, and the distinctive meaning of "corporation" in English has become fuzzier.

28. There were, for example, different rules about whether creditors suing to recover debts had to exhaust all partnership assets before proceeding against one or more partner's individual assets.

29. Although there were numerous close (private) companies organised under general corporation laws in earlier decades, the formal US legal equivalents of the British private company- "limited liability companies"-were only introduced by Wyoming as late as 1977 and were numerous nationwide in the United States only from the 1990s. Many American books published before this recent divergence of legal definition from common usage still treated "(limited liability) company" and "corporation" as synonyms, as in modern British English.

30. English-speakers in Australasia, India, Singapore, Hong Kong, and the like, as in the UK, still generally treat private limited liability companies as corporations proper, like other joint stock companies. 
that were corporate (in the Anglosphere's sense) and in which everyone, including the top managers, had limited liability, one combines the types in the first two columns, making small adjustments. ${ }^{31}$ To include registered enterprises in which outside investors-but not designated principals or managing partners-had limited liability, one needs to add limited partnerships and some cases from column 5 . To include all capitalist multi-owner entities, one further adds unlimited partnerships and more cases from column 5, again correcting for odd exceptions. ${ }^{32}$ Practicalities are more difficult than principles. Ordinary partnership data are full for Japan (at least for commercial code kaisha, though not for civil code kumiai), but are often only partial or nonexistent for other countries. Such gaps in the statistical record leave some inevitable lacunae in comparative measures.

Japan has fuller data for its kaisha (the first four columns) than the equivalents in most countries, facilitating examination of some variations resulting from alternative definitions. In Table 1, following a common convention, we counted as corporations only the first two columns. For Japan (before 1940) this includes only the first column, the KK, though one might view this with equanimity. Japan as yet had no formal private company form, but many KKs-as with the basic corporation in other countries-were de facto private, ${ }^{33}$ in the sense that they had few shareholders and their shares were not traded publicly, so companies in some respects resembling the German $\mathrm{GmbH}$ are actually included. Moreover, the differentiation is logically uniform: Both limited and unlimited partnerships are also excluded from all countries' totals. Thus, as a measure of fully limited kaisha entities, the totals in Table 1 serve reasonably well for international comparisons. ${ }^{34}$

However, there are indications that Japanese limited or ordinary partnerships (in addition to being distinctively described as kaisha or "corporate" in Japan's idiosyncratic legal terminology) and some

31. In many jurisdictions, by 1900 limited liability was a necessary feature of incorporation, but that was not true before 1850 (when limited liability was less commonly specified in corporate charters). There were still exceptions: Some UK-registered companies had unlimited liability and all California corporations until 1933 had only proportional liability. The table omits Western cooperatives and mutuals; some of these (and some Japanese kumiai in the table) had limited liability.

32. As we have noted, a few of these had de jure single owners and more de facto single owners.

33. The terms kabushiki hikōkai kaisha and kabushiki kōbo kaisha exist in Japanese only as translations of foreign terms (public and private/close companies/ corporations in the Anglosphere).

34. The exceptions in note 36 apart, with the additions of some older forms such as bergrechtliche Gewerkschaften (see note 19). 
kumiai were prone to fulfill functions sometimes undertaken by corporations proper in other countries, despite many of them having (partially or fully) unlimited liability. Table 3 puts some numbers on the issue for 1910. It is clear that counting KKs alone only just captures most entities with fully limited liability in 1910, and captures less than half of those with any limitation of liability or with separate legal personhood. It is the cooperatives (mainly special agricultural kumiai) that make up most of the numerical deficit in 1910 and that would increase if we had statistics on other kumiai. Moreover, even omitting kumiai (as other countries' statistics omit cooperatives, which they appear to have used less intensively than Japan), ${ }^{35}$ kaisha partnerships (combining goshi and gomei-i.e., those with and without some limited partners) also outnumber KKs. However, corporations (KKs) are on average much larger, so they account for 85 percent of paid-up kaisha capital in 1910. Neither would their dominance be much diminished if we added the paid-up capital of special kumiai, whose numbers grew more slowly and were smaller than kaisha and many of which lost their limited liability status in the 1930s. ${ }^{36}$ Goshi kaisha proliferated at twice the rate of KKs in the quarter century after 1910 (their numbers peaked in 1936), with gomei kaisha numbers also growing faster than KKs, but both kinds of partnership kaisha remained mainly smaller firms, ${ }^{37}$ while the average paid-up capital of KKs more than doubled. Thus the KK share in all kaisha paid-up capital remained at 85 percent in 1935, as in 1910.38

This numerical expansion and stable capital share of partnerships differs from continental European experience in this period, where the commandite was in relative decline in both numbers and paid-up capital, particularly, as in the cases Guinnane et al. emphasize, in

35. If Woytinsky's (Welt, p. 161) estimate of 130,000-140,000 cooperatives worldwide around 1920 is correct, although it is clear there are some lacunae in his figures (ibid., pp. 156-171).

36. The Financial and Economic Annual of Japan began publishing statistics on their capital only in 1928, reporting statistics back to 1917, suggesting similar small sizes to those indicated by the partial data in Japanese sources for 1910. The special kumiai numbers had increased to 15,028 by 1935 , although the average capital of the $92 \%$ reporting had grown to $¥ 18,753$ and by 1939 only 726 had fully limited status, many having been pressured to increase their capital and guarantors (Financial and Economic Annual of Japan 1940, pp. 114-115).

37. There were notable exceptions. The peak Mitsubishi and Sumitomo holding companies remained goshi kaisha until 1937 and Mitsui family control was exercised by a peak gomei kaisha until 1940, though many of their subsidiary and associated companies were KKs (Japanese judges did not share the U.S. distaste for hybrids, such as partnerships owning corporations). The changes were motivated by new double taxation of family partnership holdings, which KK holding companies avoided.

38. Financial and Economic Annual of Japan 1940, p. 217. 
Table 3 Main Japanese multi-owner enterprise forms in 1910

\begin{tabular}{|c|c|c|c|c|c|c|}
\hline & \multicolumn{4}{|c|}{ Numbers (by liability status) } & \multicolumn{2}{|c|}{ Paid-up Capital } \\
\hline & Limited & $\begin{array}{l}\text { Partly } \\
\text { Limited }\end{array}$ & Unlimited & Total \% & $¥$ Million & $\%$ of Known \\
\hline Public company (KK) & 5,026 & 0 & 0 & 26 & $1,244.5$ & 84 \\
\hline $\begin{array}{l}\text { Limited partnership } \\
\text { (goshi kaisha) }\end{array}$ & 0 & 4,783 & 0 & 24 & 96.2 & 6 \\
\hline $\begin{array}{l}\text { Ordinary partnership } \\
\text { (gomei kaisha) }\end{array}$ & 0 & 0 & 2,499 & 13 & 140.7 & 9 \\
\hline Special kumiai* & $\underline{4,204}$ & 166 & $\underline{2,889}$ & $\underline{37}$ & $\underline{5.2}+$ & $\underline{0}$ \\
\hline Total (of known) & $\underline{9,230}$ & $\underline{4,949}$ & $\underline{5,388}$ & $\underline{100}$ & $\underline{1,486.6}$ & $\underline{100}$ \\
\hline
\end{tabular}

Source: Department of Finance, Twelfth Financial and Economic Annual of Japan 1912, pp. 83, 86.

* Sangyo kumiai under the 1900 Industrial Association Law (see Sangyo kumiai yoran), which had a choice of liability status: limited (yugen kumiai) and unlimited (mugen kumiai) are self-explanatory; the "partly limited" in the table (hosho sekinin) had chosen something in between e.g. double liability). In addition to the 7,259 shown in the table there were 49 whose liability was not classified. Many of these kumiai were closer to Western rural cooperatives than to companies, but shigaichi shinyo kumiai (city credit associations, which took deposits from nonmembers and were able to discount bills) and shigaichi kobai kumiai (city consumer cooperatives) were also formed under this law. Other kumiai seem to have been less numerous-for example, there were 3,421 fishermen's associations (suisan kumiai) in 1910, but their numbers then rapidly declined; and 916 juyo bussan dogyo kumiai (trade associations) in 1912 (the earliest year), numbers that had slightly declined by 1930.

+ Paid-up capital data refer to 3,527 kumiai: less than half the total numbers.

countries that adopted the GmbH/SARL (private company) form. ${ }^{39}$ Shimizu argues that limited partnerships (goshi kaisha) and private companies (yugen kaisha) were more similar in Japan than their European equivalents. ${ }^{40}$ Goshi kaisha had separate legal personalities, like corporations, and might more readily survive the departure of a partner. However, even in Japan, dissatisfied partners in a gomei kaisha could still compel premature dissolution through withdrawal (at the end of a business year and with six months' notice), although limited partners (or their heirs) in a goshi kaisha could withdraw only if all general partners agreed, ${ }^{41}$ whereas withdrawal (as opposed to share sale) was forbidden in yugen kaisha, providing fuller entity shielding. Goshi kaisha also differed from KKs or yugen kaisha in that at least one partner had to have unlimited liability (and, in respect to debts incurred while the person was a partner, that liability subsisted for two years after withdrawal), but in practice, until a change in the law in 1938 that made it easier to enforce judgments

39. By 1925, Germany, Austria, the UK, Poland, and France (and some countries in their empires) had adopted the private company form.

40. Shimizu, "Management," pp. 11-13.

41. Vogt and Heath, Commercial Code, pp. 22-27, 36-38. Partnerships were automatically dissolved if all general or all limited partners withdrew, but it was easy to convert to gomei status if the latter occurred, and from 1911 it was possible also to convert from gomei to goshi, attracting limited partners to replace unlimited partner withdrawals. 
on unlimited partners, the procedure for outside creditors to attach assets for partnership debts was onerous. Goshi kaisha had other advantages for small family enterprises. They were cheaper to register than KKs, ${ }^{42}$ did not have to appoint auditors or publish accounts (secrecy was prized by family companies, as well as by group holding companies ${ }^{43}$ ), required only two rather than seven members, and had no minimum capital requirement. ${ }^{44}$ Partnership agreements could also entrench family control, protect minorities (through withdrawal rights of unlimited partners for reasonable cause) and allocate rights and duties more flexibly than shareholders (who had to have equal votes per share in KKs, with only a 50 percent majority required for major changes).

Goshi kaisha were the smallest of registered kaisha in Japan, with less than a tenth the average capital of KKs in 1910 (less than a twentieth by 1935) and only around one-third the average capital of ordinary partnerships at both dates. They thus occupied a position in the size hierarchy different from the ostensibly similar commandite limited partnerships in the West, which recruited limited partners to amass greater resources than unlimited partnerships. We do not have comparable capital measures for all German enterprises (only for AGs and $\mathrm{GmbHs}$ ) but, in employment terms, German KGs (limited partnerships) were about eight times the size of OHGs (unlimited partnerships) and somewhat larger than $\mathrm{GmbHs}$ (private companies). ${ }^{45}$ In the United States, also, limited partnerships were of intermediate size. ${ }^{46}$ Japanese KKs, like AGs in Germany or corporations in

42. In 1912, $0.4 \%$ of capital for gomei or goshi kaisha against $0.5 \%$ for KKs (Tanaka, Genko, p. 37), although by 1936 the standard fee was $0.5 \%$ for all kaisha with a minimum of $¥ 20$ (Mizoguchi, Toki, pp. 378, 400, 407).

43. See Kaisha Tōkeihyo. In 1927, 500 kaisha were holding companies, most of them gomei (214) or goshi (157) kaisha, not KKs, and the partnership holdings had larger capitals than KK holdings. In other countries, large holding companies were usually corporations, not partnerships (which, in some jurisdictions, were not allowed to control corporations).

44. Even in KKs the minimum capital requirement ( $¥ 140$ authorized or $¥ 87.5$ paid-up), as in Switzerland, but unlike Germany, was trivial.

45. In the 1907 German census, AG establishments, on average, had 179 employees (underestimating relative AG size because AGs were most likely to have multiple establishments), KGs 79, GmbHs 49, and OHGs (ordinary partnerships) only 7.

46. In the United States manufacturing census of 1909, corporations employed an average of 76 blue-collar workers and all partnerships an average of 12 . Sizes for the two kinds of partnerships are not reported separately but for earlier evidence that, as in Germany, they were larger than ordinary partnerships, see Hilt and O'Banion, "Limited Partnership." There were 43 times as many manufacturing establishments in U.S. corporations and ordinary partnerships combined than in limited partnerships in 1909; the comparable figure for German manufacturing in 1907 was 59 times. However, for all industries in Japan in 1907, the comparable multiple was less than 1.7 times. Thus limited partnerships were already, in relative terms, massively more important in Japan before 1914 (and became more so by the 1930s). 
the United States, occupied the top of the firm size hierarchy, but unlimited partnerships (gomei kaisha), in opposition to the norm in Western countries, ${ }^{47}$ were larger than limited ones (goshi kaisha). It was the latter-with outside investors' liability limited and freedom from accounts publication-that fulfilled a role similar to $\mathrm{GmbHs}$ in Germany. That explains both why goshi kaisha substantially declined (in numbers and share of kaisha capital) ${ }^{48}$ with the introduction of the yugen kaisha (formally the $\mathrm{GmbH}$ equivalent) ${ }^{49}$ in 1940 and also why Shimizu reports that the advantages of the $\mathrm{GmbH}$ identified by Guinnane et al. were not a primary reason for the subsequent rising popularity of the yugen kaisha in Japan. ${ }^{50}$ In the 1920s the Tokyo Chamber of Commerce and Industry lobbied for a $\mathrm{GmbH}$ for small companies, but were successful only when a tightening up of newspaper publicity requirements and other rules for KKs seemed unreasonably onerous for small firms. Yugen kaisha were introduced in 1940 and were initially nearer in size to KKs than goshi kaisha, ${ }^{51}$ but smaller firms later predominated and, just as Guinnane et al. show for Germany and France, the use of limited partnerships declined. ${ }^{52}$ One advantage of the yugen kaisha was extending limited liability to the top owner-managers, at least one of whom had to accept liability in

47. Perhaps because many unlimited partnerships in Japan were organized not as gomei kaisha under the commercial code, but under the civil code as kumiai, so reported numbers are biased to large holding partnerships and omit some small partnerships, similar to those counted in the U.S. and German statistics.

48. By March 1949 both forms of partnership kaisha were down to 24,451 ( $17 \%$ of corporations proper) and by 2009 there were only 6,056 left (only $0.5 \%$ of the number of corporations).

49. It is oversimplifying to describe the yugen kaisha as a copy of the German $\mathrm{GmbH}$. There was no restriction on the numbers of holders in a German GmbH (and a few had more than a thousand owners), but the yugen kaisha (following the British 1907 legislation) was limited to a maximum of 50 shareholders. On the other hand, the British private company had no minimum capital size, whereas the yugen kaisha had a minimum of $¥ 10,000$ capital $(\$ 2,344$ at 1940 controlled exchange rates, higher than most U.S. limits but a lower minimum than Germany's M20,000 $(\$ 7,994)$, though arguably about the same in terms of financial affordability to the local bourgeoisie). This minimum was raised to $¥ 100,000$ in 1951 (though, post-inflation, that represented a substantial reduction in real terms) and to $¥ 3$ million in 1990 (when a minimum capital requirement was also first introduced for KKs at ¥10 million; see Nicholas, “Organization”).

50. Shimizu, "Organizations" and "Management."

51. In 1940, the average capital of 2,091 yugen kaisha was $¥ 31,781$ and of $35,497 \mathrm{KKs} ¥ 69,123$ (and 6,981 KKs with capital less than $¥ 50,000$ had an average of $¥ 20,290$ ).

52. See note 5 . The requirement of yugen kaisha for a supermajority of $75 \%$ with at least $50 \%$ of voting rights represented for changes on important matters (compared with only a 50\% majority for KKs) and the possibility of shares with multiple votes (banned in KKs) also created a wider range of choices in such private companies for minority protection or qualified majority dominance, but this choice was more constrained than in Germany or the UK. 
a goshi kaisha. ${ }^{53}$ However, other advantages of the GmbH-notably, the freedom from compulsory accounts publication and flexibility in governance arrangements-were already widely adopted by Japanese SME entrepreneurs in the goshi kaisha. It is nonetheless possible that partnerships in Japan were less effective than KKs. Nicholas shows that their returns on equity were lower than KKs in 1922-1938, ${ }^{54}$ an observation compatible with a dual economy interpretation of enterprise forms. SMEs, often using the partnership forms, perhaps occupied the less profitable niches in a developing economy with many backward sectors, though all kaisha forms were present in most industries. ${ }^{55}$

Thus, the limited partnership (goshi kaisha) was more popular in its heyday in 1930s Japan than its German equivalent (the KG), despite Nazi policy favoring the conversion of AGs and GmbHs to KGs. ${ }^{56}$ To find proportions of extant registrations in the limited partnership form as high as in 1930s Japan in Germany (or other civil-law countries), one has to go back to the early nineteenth century-that is, to before general registration laws made individual authorization of corporations unnecessary ${ }^{57}$-or to countries like Russia, where the tsar's authorization was still required at the time of the 1917 revolution. ${ }^{58}$ There was, however, nothing uniquely Japanese in flexible responses to the absence of the specific $\mathrm{GmbH}$ corporate form that Guinnane et al. praise. Although commandite partnerships were not used in twentieth-century Europe as widely as the Japanese goshi kaisha, ${ }^{59}$ KK equivalents (the AG in Switzerland, the NV in the Netherlands, or

53. The government specified a minimum capital of $¥ 10,000$, fearing that individuals would use the yugen kaisha to obtain limited liability (in a goshi kaisha, at least one partner had unlimited liability and there was no minimum capital requirement). For Shimizu ("Management”), the dominant motivation was the fuller management integration needs of mergers of multiple sole proprietors required by government wartime concentration policy, while retaining shareholder participation. He also mentions safe within-family ownership dispersion, and national and local government and business association endorsement of the form, as factors encouraging diffusion of the yugen kaisha.

54. Nicholas, "Organization." His finding is particularly surprising because, in countries like the United States and UK, partnerships (and sole proprietors) have higher measured rates of return on capital than corporations, an observation usually explained by partnership profits including some returns to managerial labour, whereas corporate profits largely exclude such returns.

55. Even in manufacturing, partnerships outnumbered KKs, though partnerships were rare among public utilities, insurance and transport kaisha. Goshi kaisha were prominent in mining, where they were the same average size as KKs (though less numerous) and were particularly numerous in domestic trade.

56. Fränkel, GmbH, p. 36; Statistisches Reichsamt, GmbH, p. 4.

57. Hannah, "Corporations."

58. Owen, Corporation,11; Bokhanov, Krupnaia, 95 n. 13; Papp, Development, p. 403.

59. Anon., "Statistique;” Viander et al., Société, 66-68, 85-88, 307-327. 
the AS or AB in Scandinavia) were more commonly used to achieve what was offered by GmbHs in Germany and goshi kaisha in Japan. This was possible because their laws for this corporate option were less stringent on matters like publicity of accounts and governance rules than Germany's for AGs. The Netherlands most closely resembled Japan, though, significantly, only after its NV law was tightened up in 1928, without permitting the besloten vennootschap (BV, equivalent to a $\mathrm{GmbH}$ ) until 1971. In the intervening decades there was, though less markedly than in Japan, extensive recourse to the commandite form. This was unnecessary in Switzerland and many other small European countries, because their basic corporate form continued to have less stringent requirements, so that form could still be widely used by SMEs and family firms. Similar recourse to the KK form was known in Japan (in fact, most KKs were small family firms) ${ }^{60}$ but was less favored there. This was because Japan's fuller disclosure requirements, the wider scope of decisions that required ratification at a general meeting, and shareholder fears of calls on unpaid capital by directors at an inconvenient time (which had largely died out in Europe in the nineteenth century) discouraged some SMEs from registering as KKs. ${ }^{61}$ However, the numbers of corporations (KKs) in Japan overtook the number of AGs in Germany in 1912 and then expanded even more rapidly. Even after the yugen kaisha was introduced in 1940, KKs remained massively more numerous than German AGs. The KK was perceived to have more prestige than the yugen kaisha, and the provisions for protecting shareholder interests in KKs long remained less stringent than those in German AGs. The KK also allowed some choices, such as restrictions on share transfers by family owners, which were not possible in a German AG, but were allowed in GmbHs. ${ }^{62}$

\section{Stock Exchanges}

As the KK form was widely used by family SMEs, we cannot assume that most KK capital was publicly traded on stock exchanges, as was

60. In $1927,85 \%$ of KKs had less than ¥1m (\$0.5m) capital and $23 \%$ had less than $¥ 50,000$ (Historical Statistics of Japan, vol. 4, 1988, 172-173), although some very small KKs continued to be traded on the TSE. By 1957 95\% of kaisha (which were then overwhelmingly corporations in the sense of Table 1, not partnerships) had less than $¥ 5 \mathrm{~m}$ (by then less than $\$ 13,889$ ) capital (Historical Statistics of Japan, 2006, vol. 2, p. 52).

61. Baum and Takahashi, "Commercial and Corporate Law," 376; Nanjo and Kasuya, "Unpaid Capital."

62. von Mehren, ed., Law, 539. 
the case for AGs in Germany. ${ }^{63}$ In Japan-as in the United States, United Kingdom, and Switzerland ${ }^{64}$-de facto close corporations (with shares rarely [if at all] traded and held by relatively few people) dominated the corporate population numerically throughout the twentieth century. ${ }^{65}$ Japan did not regulate KKs as stringently as Germany's 1884 code regulated AGs, nor did it emulate the tough additional German stock exchange regulation of 1896-1897, which affected quoted AGs. ${ }^{66}$ Such laws reinforced the gatekeeper position of German banks and required AG accounts, prospectuses, and other investor aids facilitating the divorce of ownership from control. ${ }^{67}$ With fewer such legal protections for investors, one might expect Japanese stock exchange development to lag behind Germany's, at least until postwar Americanization promoted investor protection. This increased Japan's score on the "anti-director" rights index (which some modern analysts consider the major driver of stock exchange development) from 1 to 5 (out of a possible score of 6).

As Table 4 reports, however, Japanese equity markets were not behind Germany's before World War I, by Rajan and Zingales's ${ }^{68}$ widely used metric of the ratio of quoted equity capitalization to GDP, and they also forged ahead of Germany's in the interwar years in quoted company numbers. One of the reasons may have been competition both among exchanges and from off-exchange trading, whereas Berlin (and Frankfurt) gradually dominated Germany's provincial exchanges and off-exchange securities trading was illegal. Unlike major exchanges abroad, Japanese exchanges encouraged trading by not charging listing fees. Japan's forty-six exchanges of 1898 fell

63. Around a third of Prussian AGs (mainly the largest ones) were quoted on a formal exchange (Statistisches Jahrbuch 1911, pp. 228, 231).

64. Before 1938, when the Swiss introduced the GmbH.

65. Rajan and Zingales count 389 Japanese companies quoted on Tokyo, Osaka, and some other exchanges in 1913, less than 6\% of the 6,562 extant KKs.

66. Although KKs did, for example, have to publish accounts, respond to investor concerns in annual general meetings, and give shares equal votes.

67. Burhop and Lehmann-Hasemeyer, "Geography”; Fohlin, Finance Capitalism; Burhop, Chambers, and Cheffins, "Law."

68. "Great Reversals.” Their data include all (Germany) or several (Japan) stock exchanges, not just the major metropolitan exchange. Although some of Rajan and Zingales's statistics have (correctly) been criticized, those for Japan and Germany appear broadly correct. Burhop and Lehmann suggest only a slight downward adjustment to Rajan and Zingales's 1913 figure, apparently adopting a stricter definition of domestic firms than RZ. Hamao et al. (pp. 53, 62) show a very similar pattern (though, of course, somewhat lower levels) for the Tokyo Stock Exchange alone in 1885-2000 and their estimate of the number of Tokyo- and Osaka-listed companies (available only to 1937; pp. 60, 65) are compatible with Rajan and Zingales's figures. The Japanese lead will be understated because, although off-exchange trading was prohibited in Germany, there was a significant OTC market in addition to the formal exchanges in Japan, in the first half of the century. 
Table 4 Stock markets: Germany and Japan 1913-1999

\begin{tabular}{lrrrrr}
\hline \multirow{2}{*}{ Date } & \multicolumn{2}{c}{$\begin{array}{c}\text { Ratio of Equity } \\
\text { Capitalization to GDP (\%). }\end{array}$} & \multicolumn{2}{c}{$\begin{array}{c}\text { Listed Companies } \\
\text { per Million Population }\end{array}$} \\
\cline { 2 - 3 } \cline { 5 - 6 } & Japan & Germany & & Japan & Germany \\
\hline 1913 & 49 & 44 & 8 & 28 \\
1929 & 120 & 35 & 17 & 11 \\
1938 & 181 & 18 & 19 & 13 \\
$1950^{*}$ & 5 & 15 & & 9 & 13 \\
1970 & 23 & 16 & 20 & 13 \\
1999 & 95 & 67 & & \\
\hline
\end{tabular}

Source: Rajan and Zingales, "Great Reversals," pp. 15, 17.

* Japan's stock exchanges were closed from 1945 to 1949 and recovery was slower than in Germany.

to thirteen by $1911^{69}$ and to eleven by 1943 , when they were compulsorily amalgamated into the Japan Exchange (with a main exchange in Tokyo and ten branch exchanges, of which two soon closed). Outside these exchanges, over-the-counter (OTC) unregulated trading of both listed and unlisted stock long remained strong (but is excluded from the table), so the precise size of the market is difficult to define, but when nine exchanges reopened in 1949, they abolished forward trading in return for a ban on this OTC trading of listed stocks. ${ }^{70}$ (Low) listing fees were introduced; by 1950, much of the postwar reorganization of stock corporations was complete. Paradoxically, Japan's quoted capital/GDP ratio reached a nadir at this time, when postwar Americanization increased statutory investor protection, although within a few decades Japan restored its lead over Germany and now has one of the most widely dispersed stock holdings in the world. ${ }^{71}$ As elsewhere, Japanese corporate size distributions were highly skewed; it seems likely that most Japanese KK capital at an early stage was in the small minority of companies that were quoted on exchanges, ${ }^{72}$ as was the

69. Tamaki, Japanese Banking, p.108.

70. Before 1949, only forward trades had to be on exchanges in Japan; spot trades could be conducted anywhere, so the exchanges' share of this market was low. U.S.-style margin trading was introduced in 1951 to stimulate demand.

71. Faccio and Lang, "Ultimate."

72. In 1900, authorized capital listed on Tokyo was about a third of all KK capital (Hamao at al, "Listing Policy," p. 61, with precise data and definitions underlying the graph kindly provided by Tetsuji Okazaki, and Financial and Economic Annual of Japan 1902) and most firms were listed and traded elsewhere than Tokyo. Similar data for 1915-1937 suggests that the TSE's share of all KK capital remained around a third during World War I, peaked at $60 \%$ in 1922 , and, after a sharp dip in 1923, remained above 50\% from 1924 to the war. By 1949-1950, an untypical year, the corporate capital listed on all Japan's stock exchanges (by then all but a few percent quoted on Tokyo) again accounted for around one-third of the authorized capital in kaisha (compare the figures in the TSE Annual Statistical Report (Shoken tokei nenpo) with those in Bank of Japan, 100-Year Statistics, p. 330). 
norm in Europe, rather than (as in the United States before 1914 or the global norm today) most corporate capital being in close (unquoted) corporations. ${ }^{73}$

Apart from a tightening of the commercial code in 1911, which strengthened directors' liabilities for negligence, ${ }^{74}$ it is difficult to see any early German-style positive impact of corporate law in protecting shareholders in Japan. It has been argued that both law and Nazi politics shifted Germany from its strong initial (pre-1914) shareholder value culture to one that stunted stock exchange growth (as shown in Table 4). ${ }^{75}$ Why did Japan, with an apparently similar commercial code, develop so differently? Historians, noting the widespread development of stock exchanges before legal protections for investors were seriously implemented, have speculated that there were alternative mechanisms protecting shareholders, such as information signaling and monitoring by investment bankers, high dividend distribution disciplining boards, and private-order regulation of corporate charters by stock exchanges of corporate charters (such as anti-director rights or transparent accounts), which promoted shareholder confidence. ${ }^{76}$ As far as we are aware, there is no study of whether interwar Japanese corporate charters voluntarily adopted good governance rules. Okazaki et al. acknowledge that shareholders held ultimate control of corporate activities through the appointment and dismissal of directors at shareholder meetings, but argue that one of the reasons for the remarkable post-1918 growth of the Tokyo Stock Exchange, far from a strengthening of investor protection, was a relaxation of the rules, enabling the exchange to trade securities already traded on the outside spot market that had not applied for listing, thus improving market liquidity. ${ }^{77}$

Another possible candidate for explaining Japan's remarkable early growth in the quoted capital/GDP ratio is the voluntary emergence of gatekeepers and information signallers trusted by investors. Signaling by influential Meiji reformers such as Eiichi Shibusawa may have been an important supplement to legal regulation in Japan, and

73. Compare Hannah, "Global Census,” 16-17.

74. Hamao et al. ("Listing Policy") note the positive impact of the 1911 change on listings on the Tokyo Stock Exchange.

75. Burhop et al., "Law."

76. Miwa and Ramseyer ("Corporate Governance" and "Value") show that before 1914, Japanese quoted companies adopted good governance practices: They drained firms of excess cash by paying high dividends, tied managerial pay to firm profits, relied on reputational sanctions in the managerial labor market, restricted managerial discretion by charter and statute, and actively recruited prominent industrialists to the board. For similar cases in the UK, see Foreman-Peck and Hannah, "UK Corporate Law."

77. Okazaki, "Corporate Governance”; Hamao et al., "Listing Policy." 
the zaibatsu may later have been an institutional substitute for weak legal investor protections. ${ }^{78}$ We thus provisionally view the strong development of Japanese stock exchanges in the interwar years as a result of intense monitoring of professional managers by large investors (in some cases, zaibatsu families), rather than wide dispersion of holdings driven by strong investor protections. It was postwar Americanization that placed stronger investor protections on the statute book, but the occupying authorities also dissolved the zaibatsu and expropriated large shareholders. If this caused a loss of valuable signaling and/or monitoring, it provides a neatly compatible explanation of the lower postwar penetration of Japanese stock exchanges. The later recovery may have been caused as much by alternative institutional innovations by main banks and keiretsu as by formal investor protections. ${ }^{79}$

\section{An Asian Model?}

Was Japanese corporate law-and the flexibility with which Japanese businesspersons used it -in some sense part of a different Asian or Asia-Pacific model of corporate development ${ }^{80}$ than its plainly European origins suggest? Not on the dimensions we have so far discussed. Japan was precocious in using corporations (and developing stock exchanges) compared with most Asians, but was by no means the only case. Singapore and Hong Kong (which adopted Western corporate laws decades before Japan) consistently ${ }^{81}$ had (and still have) more corporations per capita than Japan, and Hong Kong had the highest ratio of quoted capital to GDP in the world as early as 1910. ${ }^{82}$ India also adopted English corporate law decades before Japan adopted the German model in 1899, yet still at the latter date had fewer corporations (though initially more corporate capital)

78. Franks et al., "Ownership," citing Okazaki’s finding ("Role”) that zaibatsu enterprises had higher rates of return in 1922-1936. Okazaki interprets this as the result of family owners being more willing to employ professional managers than firms with dispersed shareholdings, a striking reversal of the Chandlerian orthodoxy, but in line with Morikawa and others on the zaibatsu. Fruin's view (Enterprise, pp. 94-95) that Japan's stock exchanges were "small, underdeveloped in terms of the range and sophistication of financial instruments, and highly speculative" is difficult to sustain.

79. Franks et al., “Ownership.” Morck and Nakamura ("Frog”) tell a similar story of strong Japanese institutions compensating for its weak securities laws.

80. As suggested notably in World Bank, East Asian Miracle and Aoki, "Towards."

81. Except briefly when Japanese military occupiers closed their companies' registries in 1942-1944.

82. Hannah, "Global Census." 
than Japan, even though Japanese corporations until that time required individual government authorization or lacked legal clarity. India's corporate numbers per capita grew steadily but slowly under British rule and, after independence in 1947, actually declined for several decades. Despite China's adoption in 1904 of a commercial code very similar to Japan's, ${ }^{83}$ China had fewer corporations even than India and, after Mao's triumph in 1949, corporations were more comprehensively suppressed than under India's disastrous "license Raj." Korea and Taiwan were well behind India in the early decades of the century, but when the Japanese authorities extended free incorporation (on their own 1899 model) to their colonies (in 1920 and 1923, respectively) there was catch-up. ${ }^{84}$ After their unexpected independence in 1945, they followed the Singapore and Hong Kong rather than Indian trajectory, continuing to develop the relatively liberal corporate regime inherited from their colonial masters.

The main differentiator of the future tigers of the Asia-Pacific region from other underdeveloped regions in the early twentieth century was the exceptionally small size of their corporations, compared with those in the underdeveloped economies of eastern Europe, Latin America, or Africa. ${ }^{85}$ The average size of Japanese KKs in 1910 was only $¥ 247,612(\$ 125,819)$, in Korea $\$ 152,431$, and their equivalents in the Netherlands East Indies (modern Indonesia) $\$ 128,260$, and in the Straits Settlements (modern Singapore and parts of Malaysia) $\$ 138,678$. If such countries had any advantage over other underdeveloped economies (where average corporate sizes of more than $\$ 1$ million were not uncommon), it seems to be the absence of crony capitalism. This limited incorporations and access to finance to favored groups in Latin America and elsewhere and depended more on states "picking winners." 86 A multiplicity of small corporations

83. Williams, Recent.

84. The first estimate for Taiwan in the Japanese language sources shows 402 corporations (KKs) with ¥287.937m capital, $78.4 \%$ of it in Japanese hands, an average size of $¥ 716,261$ in 1929 (Takahashi, Gendai , 435-6). There were also 357 limited partnerships and 59 ordinary partnerships-a smaller relative number than in Japan—making a total capital of $¥ 312,447,000$. The equivalent Korean figures for KKs only in 1929 are $¥ 582.246$ m (an average of $¥ 724,187$ for $804 \mathrm{KKs}$ ), compared with $¥ 11,762.7 \mathrm{~m}$ (an average of $¥ 619,252$ for $18,995 \mathrm{KKs}$ ) for Japan proper. The ratio of these capital figures to GNE is $71.9 \%$ for Japan, $32.5 \%$ for Korea, and $37.2 \%$ for Taiwan, suggesting that the colonies resembled each other more than the mother country. The numbers of corporations (KKs) in 1929 per million people-88 in Taiwan, 40 for Korea, and 300 for Japan-compares with figures of 4 per million people for Korea (with an average capital of $¥ 140,415$ ) and 101 per million for Japan (with an average capital of ¥247,612) in 1910 (Hannah, "Global Census,” Table 3). The figure for India in 1910 was 12.

85. Hannah, "Global Census," p. 565.

86. Versions of crony capitalism intensified in some of these societies after independence. 
perhaps encouraged Schumpeterian creative destruction-multiple foundations and multiple bankruptcies_and a more successful, risk-taking growth model than crony capitalism. However, the largest Asian populations suffered similarly to unsuccessful non-Asian models: The average size of Chinese corporations in 1910 was as high as $\$ 1,314,851$ and, in India, $\$ 410,339$. That structure left less room for creative destruction there.

Similar relativities are observable for companies quoted on stock exchanges. The average size of 389 Japanese companies quoted on Tokyo, Osaka, and some other exchanges in 1913 was, in dollar terms, ${ }^{87}$ only $\$ 3.2$ million, compared with $\$ 34.9$ million for the 298 listed on the New York Stock Exchange about the same time, $\$ 4.8$ million for the 910 listed on the Berlin Bourse and \$14.1 million for the 1,198 listed on the London Stock Exchange. Japanese quoted KKs were also smaller than the \$16.4 million average for the 117 listed Argentine companies, $\$ 9.6 \mathrm{~m}$ for the 75 listed Egyptian companies, or $\$ 7.1$ million for the 113 listed South African companies. ${ }^{88}$ This was partly because of Japan’s low minimum listing size: paid-up capital of only ¥75,000 $(\$ 37,500)$ had been required since 1894 and, even when this was raised for new listings for forward trades, many small companies continued to be traded on the spot market. Furthermore, after railway nationalization in 1905, Japan (like Germany and South Africa) lacked this large formerly quoted sector, which still dominated many other stock exchanges.

The average corporate size in Japan will, to some extent, be understated because neither the overall KK statistics nor the stock exchange statistics group corporate subsidiaries into zaibatsu holding company groups, the major ones until the war typically controlled by (unquoted) family partnerships, not KKs. ${ }^{89}$ Seven major zaibatsu accounted for 17.5 percent of the paid-up capital of all KKs in 1928, ${ }^{90}$

87. At that time, $\$ 1=¥ 2$.

88. Hannah, "Global Census," p. 565 and online appendix. Firm size distributions are highly skewed, tending toward the lognormal, so the reported sizes are sensitive to the cutoff points implied by different numbers of listed firms averaged. It is also important to make international comparisons at market rather than par because Japanese (and many other) shares generally traded well above par, whereas U.S. shares before 1914 traded below par. The alternative view of Franks et al. ("Ownership," p. 2592) on "the relatively large average size of companies listed on the Japanese stock markets" is based on Japan having fewer listed companies but a higher ratio of capital to GDP than other countries in 1913-1915, without noting that Japan's GDP was relatively small.

89. See note 37.

90. Morikawa, Zaibatsu, p. xix. Comparison with the Ministry of Commerce data suggests Morikawa used all kaisha capital as the denominator, although by this time the zaibatsu had organized most subsidiaries as KKs. We have adjusted his reported $16.5 \%$ percentage (actually 16.6\%) upward, as all KK capital is a more suitable denominator for comparisons with Hadley's 1937 and overseas data. 
nine zaibatsu controlled several hundred KKs with 15.1 percent of paid-up capital in 1937,91 and their dominance was then accentuated under wartime controls. ${ }^{92}$ However, some 98 percent of KKs with 85 percent of KK capital were not in major zaibatsu in 1937; these included most of Japan's fifty largest enterprises, many listed on stock exchanges, with shares more widely dispersed than closely held zaibatsu subsidiaries.

Moreover, Japan was not unique in these dimensions. All countries' corporate size distributions are highly skewed (with several giants and numerous small companies) and many enumerated in other countries were also subsidiaries of interlocking enterprise groups and corporate pyramids. ${ }^{93}$ Gardiner Means, now celebrated mainly for his work with Adolph Berle on the decline of American insider ownership, actually concluded that four interlocking business groups dominated by the Rockefeller, Du Pont, and Mellon families and Morgan financial interests in 1935 controlled more than 23 percent of U.S. corporate assets. ${ }^{94}$ They thus dominated the U.S. economy more than the leading family zaibatsu in Japan and, in absolute terms, were much larger. There were also smaller interlocking groups in both countries. The American New Deal bureaucrats occupying Japan in 1945 faced few constraints and forcibly dismantled its enterprise groups, whereas in the United States they had to make do with anti-holding company laws, taxes on intercorporate shareholdings, and antitrust measures against similar pyramided groups. The U.S. groups shared features with, but were not identical to, the zaibatsu, ${ }^{95}$ although the Mellon

91. Hadley, Antitrust, 54-55. Her data are from the postwar Holding Company Dissolution Committee, using Takahashi and Aoyama's 1937 definition of zaibatsu, which is wider than the one modern scholars favor. Morck and Nakamura say that the "big 8" had 449 subsidiaries in 1937 (and the "big 10" 1,200 in 1945).

92. Hadley (Antitrust, p. 49) gives a figure of $35.2 \%$ of KK capital for ten zaibatsu in 1945, but both wartime distortions and larger disagreements among ministries on the size of the denominator make this less reliable than earlier indicators. On the wartime disruptions of capital and management, see Okazaki, "Japanese Firm."

93. Morck and Nakamura also cite family pyramids in modern France, Italy, Korea, Canada, and Sweden.

94. Authors' calculation from National Resources Committee, Structure, $308 \mathrm{ff}$. The four groups' ownership share was higher in railroads and utilities (each 38\% of all corporate assets) than in banks and industrials (each 16\%). The definitions used in the U.S. and Japanese statistics differ: The United States stringently includes only seven Rockefeller and four Du Pont corporations, while excluding some in which they had substantial holdings but over which they exercised looser control. The unincorporated business sector was also larger in Japan, biasing the result in favor of finding a higher Japanese share of all business for groups.

95. Scholars disagree about the nature, role and significance of American, Japanese, and other corporate groups, see Hilt, "History"; Morck, "Riddle"; TNEC, Bureaucracy; Bank and Cheffins, "Corporate Pyramid Fable”; Kandel et al., "Business Groups"; Colpan et al., Oxford Handbook. 
interests perhaps came closest in terms of degree of diversification and nature of interlocking controls. In Germany, also, similar holding company groups (Konzerne) with subsidiary and associate companies increased the average size of grouped companies above that shown in the unadjusted corporation or stock exchange statistics. ${ }^{96}$

One aspect of Anglo-American commercial law that initially struck many Asians as odd (in addition to fully limited liability joint stock corporations) was joint and several liability in partnerships, by which all partners-or any one of them-were liable for all partnership debts to the full extent of their assets inside and outside the partnership. In much traditional Asian law, it seemed more equitable when a partnership failed for the active partners to share liability for its debts in proportion to their shares in capital or profits, although in China creditors might bargain to adjust the normal settlement according to the relative wealth of the partners, and in the Japanese civil code equal (but not joint and several) liability was accepted when partners had not disclosed their respective shares. A conflict with traditional notions of equity may be one reason why the take-up of Western-style partnerships in China's 1904 commercial code was so low. Even in Hong Kong, where Chinese entrepreneurs more enthusiastically espoused Western laws, the British authorities proved more flexible than Manchu legislators on the mainland, adding to the enterprise menu in 1911 a partnership form for the Hong Kong Chinese that conformed more closely to native preconceptions. ${ }^{97}$ Although there was no similar modification of the Japanese commercial code, this was arguably because the contractual options for liability and governance in goshi kaisha and in civil code kumiai partnerships already left considerable scope for traditional-minded Japanese to mold their enterprises to a culturally congenial form and, for a time, to ignore newfangled Western models that the Meiji elite were keen to promote (and that eventually predominated).

\section{Conclusion}

Our international comparisons suggest that civil-law countries such as Japan or Switzerland can-as they develop-incorporate businesses as abundantly as common-law countries and that the critical

96. Liefmann (Kartelle, 314) suggested that $18 \%$ of AGs with $62-63 \%$ of AG common stock were part of Konzerne. This clearly included hundreds of groups, many more than the US and Japanese figures, though the IG Farben and Vereinigte Stahlwerke groups alone accounted for $10 \%$ of AG capital.

97. Hong Kong Ordinance 53 of 1911 offered a Chinese-style proportional liability option for partners; see Jamieson, Chinese Family, 121, 127-129. 
element in organizational menus facilitating this is liberal flexibility, not any specific legal form like the $\mathrm{GmbH}$. Our thesis is not that corporate laws and their political underpinnings have no consequences, but that the existing literature exaggerates both the negative effect of civil-law legal families and the positive effect of GmbH-type forms in determining national levels of corporatization. There is not one (or another alternative) ideal legal pathway: Many different menus of business forms have facilitated entrepreneurs creatively molding superficially incomplete menus to their tastes, especially if they included relatively unconstrained and cheap access to some form of liability limitation with entity shielding; reasonable choices among the different governance rules appropriate for both SMEs and large quoted companies; and the right cultural or regulatory impetus toward sensible choices among them. To that extent, differences in corporate laws in mainstream capitalist countries constitute only minor variations on a standard story of evolving patterns of organizational development on corporate lines, promoting both larger-scale and competitive diversity. ${ }^{98}$

Did high levels of corporatization propel countries to achieve high GDP per head? Evidence on the developmental role of companies is less clear than that on the causes of high corporatization. Views extend from skeptics such as Ronald Coase (once any clear property rights are established free market exchange will sort everything out), Joan Robinson (joint-stock companies are secondary details; by and large, "where enterprise leads, finance follows") and Robert Lucas (professional economists overplay the role of institutions supporting capital accumulation) to the large opposing literature claiming a beneficent causal connection running from the development of efficient financial and corporate institutions to modern economic growth. ${ }^{99}$ At the most basic level, there can be no serious doubt that corporate laws are important for the successful development of capitalist economies. ${ }^{100}$ Douglass North and his collaborators emphasize that "open access" political and economic orders (especially democratic regimes allowing free incorporation) are conducive to sustained

98. As was arguably even true of earlier evolutionary stages before statutory provision for general incorporation by simple registration-i.e., in Japan before 1899 or in England before 1844; on the latter, see Bubb, "Choosing."

99. Atack and Neal, Origins, pp. 4-5, arguing that the positive view is dominant, cite Robinson, but not Coase or Lucas, for the negative view; Zingales, "Does Finance Benefit Society?" notes post-GFC challenges to the positive view.

100. Rosenberg and Birdzell, How, pp. 189-241, provide a classic account of corporate advantages; Foreman-Peck and Hannah, "Diffusion," provide some econometric evidence on the relation between high levels of corporatization and GDP growth. 
economic growth. ${ }^{101}$ Although some "proofs" of that proposition verge on the tautological, they become less so if we look at regimes suppressing corporations, as in Soviet Russia for six decades after 1917 or Communist China for three decades after 1949 (three decades did less damage than six). Sometimes, even in less overtly communist societies, unfriendly governments can suppress corporate numbers growth for decades, as did Germany for two decades before 1945 or India's "license Raj” for several decades after 1947. Both eventually (and productively) abandoned their illiberal experiments as clearly as communist dictatorships.

Showa Japan had its share of authoritarian governments, but they generally remained as favorable as Meiji autocracy or Taisho democracy to developmental capitalism. ${ }^{102}$ Thus, Japan never suffered declines in corporate numbers over many decades, although the numbers of kaisha (all kinds) did decline briefly in 1903-1904, 1921-1922, 19361937, and 1944-1945 (as well as for several years of the post-1989 stagnation). One of the requirements of a passage to "modernity"-to which its elites more clearly committed Japan than did most developing countries-is a liberal process of incorporation by simple registration. That was what an international meeting of corporate lawyers in Paris in 1889 advised for all modern societies ${ }^{103}$ and that was what Japan introduced in its 1899 commercial code.

On the other hand, the criticality of more specific corporate laws hypothesized by La Porta et al. and Guinnane et al. may be doubted. The case for a basic form of limited liability is clear, but the Japanese experience confirms doubts about whether it matters whether countries adopted common or civil law systems; relied on English, French, or German stems; or formally allowed particular statutory forms, such as the $\mathrm{GmbH}$. As long as there was some variety of organizational choice, easy and cheap registration, reasonable tolerance of private contracting for governance and liability rules, and/or a generally liberal government approach to private multi-owner organizations, capitalists—and, particularly, SMEs—appeared to be able to fashion organizational forms to their own needs. They tended to avoid unnecessary expense or complication and spent few sleepless nights worrying about the arcane issues that animate corporate lawyers. Japanese businessmen were especially slow to hire lawyers (fewer in number than in Western societies), preferring ad hoc face-to-face re-negotiation (based on common sense and continuing mutual interests) to courtroom

101. North et al., Violence.

102. See Okazaki ("Japanese Firm") for Takahashi's 1930 book and anti-shareholder sentiment.

103. Ministère, Compte-rendu. 
tussles, when business circumstances required contractual or governance modifications.

The importance of contractual flexibility and liberal political stances over notionally "perfect" lawmaking can be seen in Russia today: Its exemplary formal corporate laws (adopted in the 1990s) were no proof against crony capitalism and corruption. ${ }^{104}$ Equally eloquent is the fate of the menu innovations introduced by wellmeaning legal reformers, convinced of their logical superiority, but underestimating the ingenuity of businesses already using viable work-arounds. The drafters of the new Japanese commercial code introduced the German KGaA (limited partnership with shares) in 1899 (while not considering the GmbH necessary), but Japanese entrepreneurs hardly used it, preferring to achieve similar objects within the KK framework. Bankers who wanted directors of corporations to accept liability for loans simply required them to guarantee the loans, rather than adopting the KGaA form.

The overwhelming majority of Japan's (and, indeed, the world's) businesses in the early twentieth century-with self-employment the norm in economies dominated numerically by farmers, craftspersons, and shopkeepers-were not kaisha of any kind, but sole proprietors. Some individuals operated collectively through family arrangements, unregistered kumiai partnerships, or other informal multi-owner forms, perhaps governed by trust, convention, and interest as much as formal law. In 1920, the first detailed Japanese employment census showed that employers (including the self-employed) still numbered 8,958,000, as much as one-third of the civilian labor force. The 29,917 kaisha of all kinds ${ }^{105}$ thus constituted less than 0.3 percent of all Japanese enterprises, and the unknown (but more numerous) total for all kumiai is unlikely to have increased the multi-owned proportion to more than a percentage point or two. On the other hand, in a developed economy like Germany, multi-owner or incorporated enterprises already constituted more than 9 percent of private sector businesses, ${ }^{106}$ and in richer societies such as the United States,

104. Pistor et al., "Evolution."

105. Bank of Japan, 100-Year Statistics, p. 326, though compare p. 330 for higher figures. The Ministry of Commerce data show only 28,676 kaisha in the same year (Financial and Economic Annual of Japan 1922, p. 85). From 1893, sole proprietors in Japan were forbidden to call themselves companies (Takata, "From Merchant House," 101).

106. Calculated from the 1907 census of Gewerbe, with all private sector establishments except those classified as sole proprietors or Alleinbetrieben (establishments with no employees and using no power) counted as multi-owner or corporate enterprises. Sole proprietors and the self-employed still then accounted for most of the private sector workforce. 
United Kingdom, or Australia, the proportion was even higher. ${ }^{107}$ In the United Kingdom-then the most industrialized economycorporations alone already accounted for most business employment and for three-quarters of all profits on capital. ${ }^{108}$ Japan's twentieth-century history is essentially the history of the growth of kaisha to become a similarly dominant enterprise form. The rise of the Tokyo Stock Exchange to rival Western equivalents in absolute size is a similarly normal trajectory for a successful industrializer, although for most of the century on this dimension Japan was ahead of many civil-law countries, including Germany.

In both the industrialized and developing worlds, private (unquoted) companies now constitute around two-thirds of the corporate sector by value or output and include many SMEs. ${ }^{109}$ This sector is arguably critical for promoting the competitive diversity on which innovation and productivity improvements thrive. Here too, the main contours of Japanese corporate development are a slight variant on a common story in advanced economies of flexible organizational menus. It did not matter that the framers of Japan's commercial code omitted the yugen kaisha until 1940; Japanese SMEs simply modified their use of what was available-KKs, goshi kaisha, and kumiai-to achieve much the same effect. Societies that allowed human capital, infrastructure, and basic property rights (modified by some form of limited liability) to work creatively toward wealth creation could relax about the finer details of their legal menus for organizational and financial contracting. The Japanese were very ordinary capitalists, doing ordinary capitalist things, like many others in Europe, Asia, and America who lacked the $\mathrm{GmbH}$.

\section{Bibliography of Works Cited}

\section{Books}

Atack, J. and L. Neal, eds. The Origins and Development of Financial Markets and Institutions. New York: Cambridge University Press, 2009.

Bank of Japan. Hundred-Year Statistics of the Japanese Economy. Tokyo: Statistics Department, Bank of Japan, 1966.

Bokhanov, A. N. Krupnaia burzhuaziia Rossii: konets XIXv.-1914 g (The Upper Bourgeoisie of Russia: From the End of the Nineteenth Century to 1914), Moscow: Nauka, 1992.

107. Nicholas ("Organization," pp. 4, 10) suggests that Japan used the corporate form more than the United States; this derives from his Japanese business count excluding sole proprietors, whereas his U.S. count includes them.

108. Feinstein, National Income, 157; Stamp, British Incomes, 303-305.

109. Mayer, p.14; see also Brav, "Access," p. 264. 
Bozio, A. La Capitalisation Boursière en France au XXe Siècle. Mémoire de DEA. Paris: EHESS, Ecole Normale Supérieure, ENSAE, Ecole Polytechnique, 2002.

Colpan, A. M., T. Hikino, and J. R. Lincoln, eds. The Oxford Handbook of Business Groups. Oxford: Oxford University Press, 2010.

Crane, J. A. Handbook on the Law of Partnerships and other Unincorporated Associations. St. Paul, MN: West Publishing, 1938.

de Becker, J. E. Annotated Civil Code of Japan, vol. 2. Yokohama: Butterworth \& Co., 1909.

Department of Commerce and Industry. Kaisha Tōkeihyo [Company Statistics]. Tokyo: Tokeigakusha, 1920-1941.

Feinstein, C. H. National Income, Expenditure and Output 1855-1965, Cambridge: Cambridge University Press, 1972.

Fohlin, C. Finance Capitalism and Germany's Rise to Industrial Power. New York: Cambridge University Press, 2007.

Fränkel, F. Die Gesellscaft mit beschränkter Haftung: eine volkswirtschafliche Studie. Tübingen: Mohr, 1915.

Hadley, E. M. Antitrust in Japan. Princeton NJ: Princeton University Press, 1970.

Jamieson, G. Chinese Family and Commercial Law. Shanghai: Kelly and Walsh, 1921.

Liefmann, R. Kartelle, Konzerne und Trusts. Stuttgart: Ernst Heinrich Moritz, 1930

Lindley, N. A Treatise on the Law of Partnership, $2^{\text {nd }}$ American ed., vol. 1, edited by M. D. Ewell. Chicago: Callaghan, 1888.

Management and Coordination Agency, Statistics Bureau. Historical Statistics of Japan (5 vols.). Tokyo: Japan Statistical Association, 1988.

Mayer, C. Firm Commitment: Why the Corporation Is Failing Us and How to Restore Trust in It. Oxford: Oxford University Press, 2013.

Ministère du Commerce, de l'Industrie et des Colonies. Congrès International des Sociétés par Actions: Compte-rendu Sténographique. Paris: Rousseau, 1890.

Ministry of Internal Affairs and Communications, Statistical Branch, Historical Statistics of Japan (5 vols.). Tokyo: Japan Statistical Association, 2006.

Mizoguchi, H. Toki tetsuzuki komon: shinsei shoshiki iri, daisho irazu [Consulting about Registration: with Application Formats]. Tokyo: Sankosha, 1936.

Morikawa, H. Zaibatsu: The Rise and Fall of Family Enterprise Groups in Japan. Tokyo: University of Tokyo Press, 1992.

National Resources Committee. The Structure of the American Economy. Washington, DC: Government Printing Office, 1939.

North, D. C., J. J. Wallis, and B. R. Weingast. Violence and Social Orders: A Conceptual Framework for Interpreting Recorded Human History. New York: Cambridge University Press, 2009.

Owen, T. C. The Corporation under Russian Law, 1800-1917. New York: Cambridge University Press, 1991.

Rosenberg, N. and L. E. Birdzell Jr. How the West Grew Rich. New York: Basic Books, 1986. 
Smith, J. W. A Handy Book on the Law of Private Trading Partnerships. London: Effingham Wilson, 1908.

Stamp, J. C. British Incomes and Property, London: Macmillan, 1919.

Takahashi, K. Gendai Taiwan Keizairon (Contemporary Taiwan Economic Essays). Tokyo: Chikura Shobo, 1937.

Tamaki, N. Japanese Banking: A History, 1859-1959. Cambridge: Cambridge University Press, 1995.

Tanaka, N., ed. Genko shozei ryokan ruishu: kokumin hikkei [Compilation of Current Taxes and Fees], Tokyo: Tanaka, 1912.

Viander, A., J. Hilaire, H. Merle, and H. Serbat. La société en commandite entre son passé et son avenir, Paris: Librairies Techniques, 1983.

Vogt, K. and G. O. Heath. Commercial Code of Japan, $2^{\text {nd }}$ ed. Yokohama: Crosse, Heath \& Vogt, 1912.

von Mehren, A. T., ed. Law in Japan: The Legal Order in a Changing Society. Cambridge MA: Harvard University Press, 1963.

Williams, E. T. Recent Chinese Legislation Relating to Commercial Railway and Mining Enterprises. Shanghai: Shanghai Mercury, 1904.

Woytinsky, W. L., Die Welt in Zahlen, vol. 5. Berlin: Mosse, 1926.

Articles, Book Chapters, and Papers

Anon. "Statistique." Bulletin de statistique et de législation comparée 115 (January1934): 41.

Aoki, M, "Towards an Economic Model of the Japanese Firm." Journal of Economic Literature 28 (March 1999): 1-27.

Bank, S. A. and B. R. Cheffins. "The Corporate Pyramid Fable." Business History Review 84 (Autumn 2010): 435-458.

Baum, H. and E. Takahashi. "Commercial and Corporate Law in Japan." In History of Law in Japan Since 1868, edited by W. Röhl, 330-401 Leiden: Brill, 2000.

Brav, O. "Access to Capital, Capital Structure and the Funding of the Firm." Journal of Finance 64, no. 1 (February 2009): 263-308.

Bubb, R. "Choosing the Partnership: English Business Organization Law during the Industrial Revolution." Seattle University Law Review 337 (2015): 237-264.

Burhop, C. and S. H. Lehmann-Hasemeyer. "The Geography of Stock Exchanges in Imperial Germany." University of Hohenheim FZID Discussion Paper 89 (2014).

Burhop, C., D. Chambers, and B. Cheffins. "Law, Politics and the Rise and Fall of German Stock Market Development 1870-1938." University of Cambridge Faculty of Law Working Paper 283, January 2015.

Cheffins, B. R. "Did Law Matter? The Separation of Ownership and Control in the United Kingdom." Journal of Legal Studies 30, no. 20 (June 2001): 459-484.

Churchill, A. C. "Cooperatives in Japan." Far Eastern Survey 14, no. 15 (August 1946): 204-207.

Coffee, J. C. "The Rise of Dispersed Ownership: The Roles of Law and the State in the Separation of Ownership and Control." Yale Law Journal 111, no. 1 (October 2001): 12-82. 
Djankov, S., R. La Porta, F. Lopez de Silanes, and A. Shleifer. "The Regulation of Entry." Quarterly Journal of Economics 117, no. 1 (2002): 1-37.

Faccio, M. and L. H. P. Lang. "The Ultimate Ownership of Western European Corporations." Journal of Financial Economics 65, no. 3 (2002): 365-395.

Fisher, G. M. "The Cooperative Movement in Japan." Pacific Affairs 11, no. 4 (December 1938): 478-491.1-2.

Foreman-Peck, J. and L. Hannah. "The Diffusion and Impact of the Corporation in 1910." Economic History Review 68, no. 3 (2014): 962-984.

—_. "UK Corporate Law and Corporate Governance before 1914: A Re-interpretation." In Complexity and Crisis in the Financial System: Critical Perspectives on American and British Banking, edited by M. Hollow, F. Akinbami, and R Michie, Chapter 7 (forthcoming, Edward Elgar, 2015).

Franks, J., C. Mayer, and H. Miyajima. "The Ownership of Japanese Corporations in the 20th Century." Review of Financial Studies 27, no. 9 (2014): 2580-2625.

Fruin, M. The Japanese Enterprise System. Cambridge MA: Harvard University Press, 1990.

Guinnane, T. W., R. Harris, N. Lamoreaux, and J-L Rosenthal. "Putting the Corporation in its Place." Enterprise and Society 8 (September 2007): 687-729.

—. "Pouvoir et propriété dans l'entreprise: pour une histoire internationale des societies à responsabilité limitée," Annales 63, 1 (2008): 73-110.

Hamao, Y., T. Hoshi, and T. Okazaki. "Listing Policy and Development of the Tokyo Stock Exchange in the Pre-War Period.” In Financial Sector Development in the Pacific Rim, edited by T. Ito and A. K. Rose, 51-95. Chicago: NBER/University of Chicago Press, 2009.

Hannah, L. "A Global Census of Corporations: Publicly Quoted and Close Companies in 1910.” Economic History Review 68, no. 2 (2015): 548-573.

- "Corporations in the US and Europe, 1790-1860." Business History 56, no. 6 (September 2014): 865-899.

— . "Weimar's Capitalist Spring: A Liberal Exception to Germany's Sonderweg in Corporate Development." In Armageddon and Mammon: the Impact of the First World War on International Business, edited by A. Smith, S. Mollan, and K. Tennent. London: Routledge, 2015, forthcoming.

Hilt, E. "Corporate Governance and the Development of Manufacturing Enterprises in Nineteenth-Century Massachusetts.” NBER Working Paper 20096, May 2014, p. 233.

- "History of American Corporate Governance: Law, Institutions and Politics,” NBER Working Paper 20356, July 2014.

Hilt, E. and K. O’Banion. "The Limited Partnership in New York, 18221858: Partnerships without Kinship.” Journal of Economic History 69, no. 3 (September 2009): 615-645.

Kandel, E., K. Kosenko, R. Morck, and Y. Yafeh. "Business Groups in the United States: A Revised History of Corporate Ownership, Pyramids and Regulation, 1930-1950.” NBER Working Paper No. 19691, December 2013.

Lamoreaux, N. R. and J-L. Rosenthal. "Legal Regime and Contractual Flexibility: A Comparison of Business's Organizational Choice in France and the United States during the Era of Industrialization." American Law and Economics Review 7, no. 1 (March 2005): 28-61. 
La Porta, R., F. Lopes-de-Silanes, A. Shleifer, and R. Vishny. "Law and Finance." Journal of Political Economy 106, no 6 (1998): 1113-1155.

La Porta, R., F. Lopes-de-Silanes, and A. Shleifer, "The Economic Consequences of Legal Origins." Journal of Economic Literature 46, no. 2 (June 2008): 285-332.

Ministry of Finance. Financial and Economic Annual of Japan. Tokyo: Government Printing Office, various issues, 1900-1940.

Miwa, Y. and J. M. Ramseyer. "Corporate Governance in Transitional Economies: Lessons from the Pre-war Japanese Cotton Textile Industry." Journal of Legal Studies 29, no. 1 (January 2000): 171-203.

—. "The Value of Prominent Directors: Corporate Governance and Bank Access in Transitional Japan.” Journal of Legal Studies 31 (2002): 273-301.

Morck, R. K. and M. Nakamura. "A Frog in a Well Knows Nothing of the Ocean: A History of Corporate Ownership in Japan." In A History of Corporate Governance around the World, edited by R. K. Morck, 367-465. Chicago: University of Chicago Press, 2007.

Morck, R. "The Riddle of the Great Pyramids.” NBER Working Paper 14858, April 2009.

Musacchio, A. and J. D. Turner. "Does the Law and Finance Hypothesis Pass the Test of History?" Business History 55, no. 4 (June 2013): 524-542.

Nanjo, T. and M Kasuya. "Part-Paid Stock, Corporate Finance, and Investment: Economic Consequences of the Part-Paid Stock System and Supplementary Installments in Early 1930s Japan." Monetary and Economic Studies 27 (November 2009): 219-246.

Nicholas, T. "The Organization of Enterprise in Japan." Harvard Business School Working Paper 14017, November 2013.

Okazaki, T. "The Japanese Firm under the Wartime Planned Economy." In The Japanese Firm, edited by M. Aoki and R. Dore, 350-378. Oxford: Oxford University Press, 1996.

_. "Corporate Governance." In The Japanese Economic System and Its Historical Origins, edited by T. Okazaki and M. Okuno-Fujiwara, 97-144. Oxford: Oxford University Press, 1999.

—. "The Role of Holding Companies in Pre-War Japanese Economic Development: Rethinking Zaibatsu in Perspectives of Corporate Governance." Social Science Japan Journal 4, no. 2 (2001) 243-268.

Papp, R. G. The Development of a Domestic Stock Market in St. Petersburg in Late Imperial Russia. Columbia University PhD dissertation, 2001 (UMI reprint 3005770).

Pistor, K., Y. Keinan, J. Kleinhesterkamp, and M. D. West. "The Evolution of Corporate Law: A Cross-Country Comparison." University of Pennsylvania Journal of International Economic Law 23, no. 4 (2002): 791-876.

Shimizu, T. "Organizations, Corporations and Shareholders: An Organizational Analysis of the Legal Structure of Business Entities.” Tokyo University Working Paper, 2012.

—_. "Management and Control in Small and Medium-sized Enterprises: The Case of Private Limited Liability Companies in Japan before World War II.” Paper presented at theWorld Business History Conference, Frankfurt, 2014. 
Statistisches Jahrbuch für den Preussischen Staat 1911, Berlin 1912.

Statistisches Reichsamt, "Die Gesellschaften mit beschränkter Haftung am 31 Dezember 1936," Statistik des Deutschen Reichs, vol. 502, Berlin, 1937.

Takata, A. A. " From Merchant House to Corporation: The Development of the Modern Corporate Form and the Transformation of Business Organization in Japan, 1853-1912." Stanford University PhD dissertation, 1994.

Temporary National Economic Committee, Bureaucracy and Trusteeship in Large Corporations, TNEC Monograph no. 11. Washington, DC: Government Printing Office, 1940.

Yamazaki, K. "Doitsu no yugen sekinin kaisha ni tsuite [On the German GmbH].” Hogaku Kyokai zasshi [Journal of the Law Association], 25, no. 4 (1907): 480-494.

Zingales, L. “Does Finance Benefit Society?' NBER Working Paper no. 20894, January 2015. 